\title{
Sensitivity of Planktonic Aquatic Bacteria to Ciprofloxacin
}

\section{Brij Verma, David Verma}

PBR Laboratories, Edmonton, Canada

Email: Brij.Verma@usask.ca

How to cite this paper: Verma, B. and Verma, D. (2016) Sensitivity of Planktonic Aquatic Bacteria to Ciprofloxacin. Advances in $\mathrm{Mi}$ crobiology, 6, 753-759.

http://dx.doi.org/10.4236/aim.2016.610074

Received: June 22, 2016

Accepted: August 23, 2016

Published: August 26, 2016

Copyright $\odot 2016$ by authors and Scientific Research Publishing Inc. This work is licensed under the Creative Commons Attribution International License (CC BY 4.0).

http://creativecommons.org/licenses/by/4.0/

(c) (i) Open Access

\begin{abstract}
Many anthropogenic compounds, such as antibiotics, are found at trace levels $\left(<\mu \mathrm{g} \cdot \mathrm{L}^{-1}\right)$ in aquatic and terrestrial systems. The effect of these compounds on the metabolism and function of microbes are difficult to assess because the assays used, such as the minimum inhibitory concentration (MIC) and the disk diffusion methods, lack the sensitivities to measure bacterial response to these very low levels of antibiotics on bacterial populations. Therefore, we theorized that the $\left[{ }^{3} \mathrm{H}\right]$ thymidine incorporation into DNA method might be sensitive in determining the effect of DNA inhibiting antibiotics on DNA production in planktonic bacteria in aquatic systems. Utilizing the ${ }^{3} \mathrm{H}$ thymidine method, we measured the effects of ciprofloxacin on DNA production on planktonic bacteria in river and pond waters. Ciprofloxacin significantly $(\mathrm{P}<0.02)$ inhibited river water bacteria at a concentration of $25 \mu \mathrm{g} \cdot \mathrm{L}^{-1}$ but significant inhibition $(\mathrm{P}<0.01)$ occurred at $1000 \mu \mathrm{g} \cdot \mathrm{L}^{-1}$ in pond water. The very low concentration required to inhibit DNA production in river water bacteria indicates that bacteria are extremely sensitive to antibiotics at very low concentrations. A likely reason for the differences in inhibition between the two waters is due to ciprofloxacin becoming bound, and possibly becoming biologically inactive, in the pond water due to higher dissolved organic carbon content. This work demonstrates that bacteria in some aquatic systems can be significantly impacted by low concentrations of anthropogenic antibiotics finding their way into these systems and that our assumptions as to the concentrations at which antibiotics affect microbes are highly underestimated.
\end{abstract}

\section{Keywords}

Planktonic Bacteria, Aquatic, Antibiotics, Antibiotic Resistance, Ciprofloxacin, Thymidine Incorporation, Bacterial Production, DNA Production, DNA Inhibition 


\section{Introduction}

Antibiotics are compounds that inhibit the growth of susceptible microbes. The vast majority of antibiotics in clinical use are derived from organisms ubiquitous in the natural environment [1]. Antibiotics are secondary metabolites, similar to phenolics in plants, produced when microbial growth slows and/or begins to enter stationary phase [2] and is often triggered by nutrient limitations. Antibiotic producing microbes can inhibit nearby microbes and thereby provide themselves time to establish a niche to grow and propagate. An antibiotic producing microbe can also gain valuable resources since susceptible microbes can die and release nutrients through decomposition which can then be utilized by the antibiotic producing microbe and its progeny. But what are the concentration levels of antibiotics at which microbes are affected? The answer to this question is largely unknown and is limited by the assay used to measure the effect of an antibiotic against a susceptible microbe.

Two very common methods used to measure inhibition or sensitivity to antibiotics by bacteria are the minimum inhibitory concentration (MIC) and the disk diffusion method [3]. The concentrations of antibiotics used in the above two methods are usually in the $\mu \mathrm{g} \cdot \mathrm{mL}^{-1}$ or $\mathrm{mg} \cdot \mathrm{L}^{-1}(\mathrm{ppm})$ range [4]. With antibiotics having been detected in wastewater effluents and aquatic systems in many countries around the world [5] [6] at concentrations of $\eta \mathrm{g}$ to low $\mu \mathrm{g} \cdot \mathrm{L}^{-1}$, the two methods above are inadequate at measuring the effects on microbial populations. We theorized that the $\left[{ }^{3} \mathrm{H}\right]$ thymidine incorporation into DNA method may be relevant and sensitive in measuring the effects of DNA inhibiting antibiotics.

Here we report the effects of ciprofloxacin, one of the most prescribed of the quinolone antibiotics in the world [7], an antibiotic that inhibits DNA production in susceptible microbes, on planktonic bacteria in river and wetland waters as measured by the incorporation of $\left[{ }^{3} \mathrm{H}\right]$ thymidine into DNA. Ciprofloxacin has been detected in the environment and wastewater from $\eta \mathrm{g}$ to low $\mu \mathrm{g} \cdot \mathrm{L}^{-1}$ [5] while concentration in hospital effluent has been measured at up to $124.5 \mu \mathrm{g} \cdot \mathrm{L}^{-1}$ [8] and a total of eight quinolones, including ciprofloxacin, at $9 \mathrm{mg} \cdot \mathrm{kg}^{-1}$ (dry weight) in sewage sludge [9]. Although the concentration of antibiotics in open waters is low, it should not be assumed that the effects on bacteria and selection pressure for resistant strains are negligible as it has been found that a constant applied dosage at a tenth of MIC has a strong influence on selecting for resistant microbes [10]. Moreover, WHO warns that the levels of bacterial resistance to antibiotics have reached to the levels where medicinal treatment for even common infections is becoming limited [11].

\section{Methods}

Sample of river water was obtained from the South Saskatchewan River (SSK) at Saskatoon, Saskatchewan, Canada $\left(106^{\circ} 38^{\prime} \mathrm{W}, 52^{\circ} 07^{\prime} \mathrm{N}\right)$ and water sample from Pond 1 $\left(106^{\circ} 06^{\prime} \mathrm{W}, 52^{\circ} 02^{\prime} \mathrm{N}\right)$ was also taken. River as well as Pond 1 water samples were collected in $10 \mathrm{~L}$ plastic bottles and stored at $4^{\circ} \mathrm{C}$ for 7 days before processing. Both water types were allowed to warm to room temperature before being used. Water chemistry 
was analyzed by suppressed conductivity ion-exchange chromatography on a Dionex 400 Ion Exchange chromatograph (Sunnyvale, California). Bacteria were enumerated by staining with 4',6'-diamidino-2-phenylindole hydrochloride (DAPI) and epifluorescent microscopy [12].

We were unsure how sensitive or effective the ${ }^{3} \mathrm{H}$ thymidine incorporation into DNA method, in the presence of a DNA inhibiting antibiotic, would be since this method has not, to the best of our knowledge, previously been used in this way. However, using our previous work [13] as well as the water chemistry of the two waters as a guide, we used ciprofloxacin (ICN Biomedicals, Aurora, Ohio, USA) concentrations of 0, 2, 12.5, 25, 250 and $1000 \mu \mathrm{g} \cdot \mathrm{L}^{-1}$. Ciprofloxacin solution was sterilised by filtering through sterile $0.2 \mu \mathrm{m}$ nylon syringe filters (Nalgene, Rochester, NY, USA) prior to being used. Bacterial production in the river and wetland waters was evaluated by measuring the relative incorporation of [methyl- ${ }^{3} \mathrm{H}$ ] thymidine (Perkin Elmer, Boston, MA, USA, specific activity $74.5 \mathrm{Ci} \mathrm{mmol}^{-1}$ ) incorporation into DNA [14]. All vials, pipettes and filters were sterilized by autoclaving. The $\left[{ }^{3} \mathrm{H}\right]$ thymidine stock was diluted to 1 part in 10 with sterile distilled water and $50 \mu \mathrm{l}$ was added to $20 \mathrm{ml}$ scintillation vials that held $5 \mathrm{ml}$ of river or pond water. The contents of the vials, all in triplicate, were gently swirled and incubated for $30 \mathrm{~min}$ at room temperature $\left(21^{\circ} \mathrm{C} \pm 3^{\circ} \mathrm{C}\right)$. Incubations were stopped by adding $500 \mu \mathrm{l}$ of formalin, followed $5 \mathrm{~min}$ later by adding $500 \mu \mathrm{l}$ of $5 \mathrm{M} \mathrm{NaOH}$. The vials were put on ice and $0.9 \mathrm{ml}$ of ice-cold trichloroacetic acid added, after which the vials were vortexed and allowed to further sit on ice for $15 \mathrm{~min}$. The vial contents were then filtered through $25 \mathrm{~mm}$ diameter, $0.2 \mu \mathrm{m}$ pore size Whatman (Brentford, UK) cellulose nitrate filters. The vials and the filters were rinsed with $1.25 \mathrm{ml}$ of $50 \%$ phenol chloroform followed by $5 \mathrm{ml}$ of $80 \% \mathrm{EtOH}$. The filters were removed and placed in fresh scintillation vials to which was then added $10 \mathrm{ml}$ of Filter Count (Perkin Elmer, Boston, MA, USA), and the vials vortexed for $5 \mathrm{~min}$ so that the filters were completely dissolved. The number of disintegrations per minute (DPM) in each vial was determined with a Packard scintillation counter by using an external standard.

Sigma Stat 5.0 and t-tests were used for statistical analysis of the data.

\section{Results}

The concentration of nutrients, salinity and dissolved organic carbon (DOC) in the Pond 1 water was greater than the river water (Table 1), while the planktonic bacterial population was similar in both systems.

In the experiment conducted in river water (Figure 1), significant $(\mathrm{P}<0.05)$ inhibition in ${ }^{3} \mathrm{H}$ thymidine incorporation into bacterial DNA occurred at 25, 250 and 1000 $\mu \mathrm{g} \cdot \mathrm{L}^{-1}$ ciprofloxacin treatments but not between the control and 2 and $12.5 \mu \mathrm{g} \cdot \mathrm{L}^{-1}$ treatments $(P>0.05)$. In the pond water experiment (Figure 2$)$ significant inhibition of DNA production, as compared to the control, occurred in the $1000 \mu \mathrm{g} \cdot \mathrm{L}^{-1}$ treatment $(\mathrm{P}$ $=0.008)$ but not between the control and any other treatments $(\mathrm{P}>0.05)$. Comparing the river water and pond water experiments to each other, significantly more ${ }^{3} \mathrm{H}$ thymidine $(\mathrm{P}<0.05)$ was incorporated into the DNA of river water bacteria as compared to the bacteria in the pond water. 


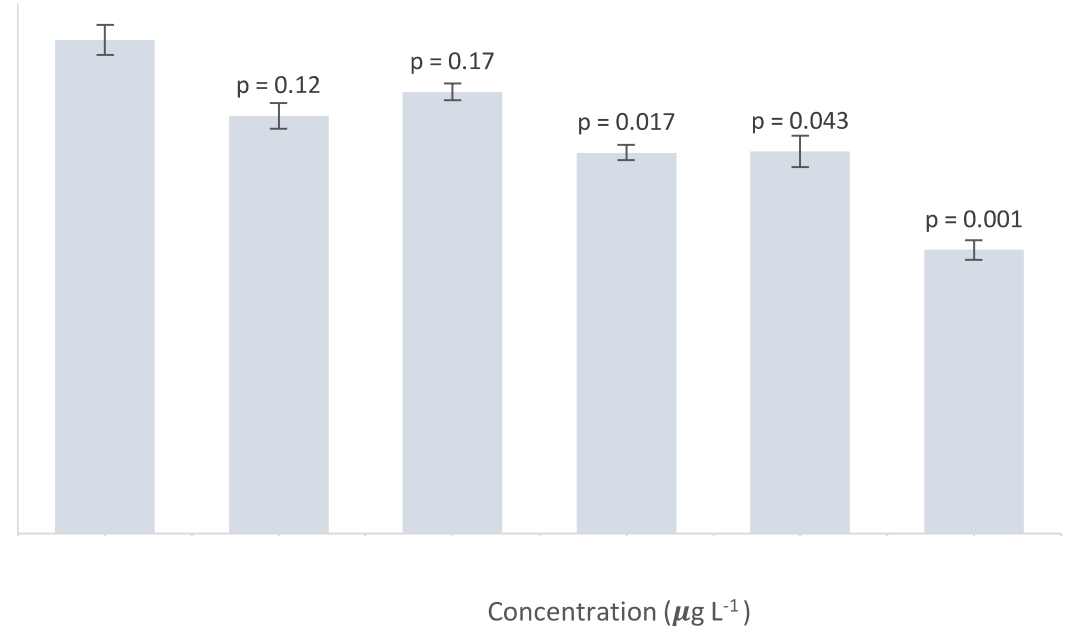

Figure 1. Effects of 2, 12.5, 25, 250 and $1000 \mu \mathrm{g} \cdot \mathrm{L}^{-1}$ of ciprofloxacin on ${ }^{3} \mathrm{H}$-thymidine incorporation into the DNA of bacteria present in South Saskatchewan River water. Treatments that were significantly different $(\mathrm{P}<0.05)$ from the control are indicated while the bars are \pm standard error.

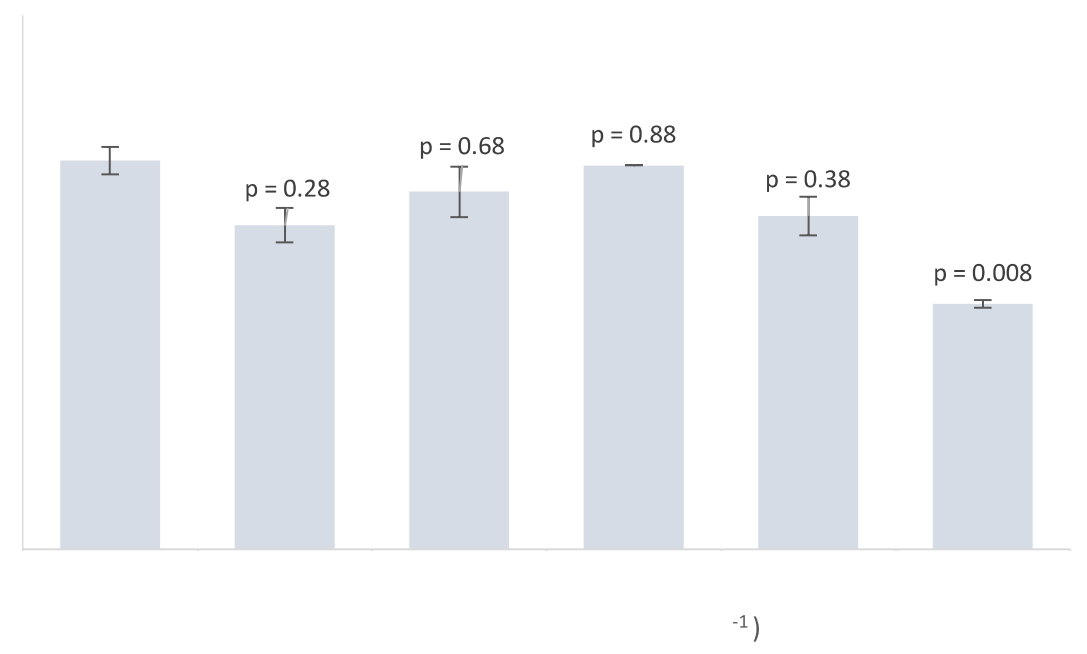

Figure 2. Effects of 2, 12.5, 25, 250 and $1000 \mu \mathrm{g} \cdot \mathrm{L}^{-1}$ of ciprofloxacin on ${ }^{3} \mathrm{H}$-thymidine incorporation into the DNA of bacteria present in Pond 1 water. Treatments that were significantly different $(\mathrm{P}<0.05)$ from the control are indicated while the bars are \pm standard error.

Table 1. Water chemistry and bacterial counts as determined by DAPI and epifluorescent microscopy (Data from Verma et al. (11)).

\begin{tabular}{cccccccc}
\hline Water & $\mathrm{Cl}\left(\mu \mathrm{g} \cdot \mathrm{l}^{-1}\right)$ & $\mathrm{NO}_{3}\left(\mu \mathrm{g} \cdot \mathrm{l}^{-1}\right)$ & $\mathrm{SO}_{4}\left(\mu \mathrm{g} \cdot \mathrm{l}^{-1}\right)$ & $\mathrm{pH}$ & $\begin{array}{c}\text { Alkalinity } \\
\left(\mu \mathrm{g} \cdot \mathrm{l}^{-1} \mathrm{CaCO}_{3}\right)\end{array}$ & $\begin{array}{c}\mathrm{DOC} \\
\left(\mathrm{mg} \cdot \mathrm{L}^{-1}\right)\end{array}$ & $\begin{array}{c}\text { DAPI counts } \\
\left(\text { bacteria } \cdot \mathrm{ml}^{-1}\right)\end{array}$ \\
\hline SSK River & 7.50 & 0.4 & 71 & 8.3 & 96 & 3.3 & $5.53 \times 10^{6}$ \\
Pond 1 & 76.0 & 1.5 & 4065 & 7.5 & 149 & 48.8 & $7.54 \times 10^{6}$ \\
\hline
\end{tabular}

\section{Discussions}

Since ciprofloxacin is known to inhibit the activities of the enzymes DNA gyrase and 
DNA topoisomerase IV in susceptible microbes [7] [15], it was expected that there would be inhibition in bacterial DNA production in the two waters. However, it was not known at what concentration of antibiotic the inhibition would become significant. The ${ }^{3} \mathrm{H}$ thymidine incorporation method was found to be highly sensitive and able to measure significant inhibition in DNA production in river water bacteria occurring at ciprofloxacin concentration of only $25 \mu \mathrm{g} \cdot \mathrm{L}^{-1}$. This is significant as it is 10 to 100 times lower than results shown using the MIC and disk diffusion methods. Our results showed that bacteria can be extremely sensitive to antibiotics at concentrations magnitudes below presently deemed and that the general assumption of low $\mu \mathrm{g} \cdot \mathrm{L}^{-1}$ concentrations of antibiotics having little or no impact on bacteria in aquatic environments is not merited and should be further studied.

While we do not have data as to the amount of ciprofloxacin that is free and the portion that is bound in the river and pond waters used in the experiments, it is known that ciprofloxacin binds strongly to particulate matter and DOC [16] [17]. This binding to organic matter, including chelation, can often make antibiotics biologically inactive [13] [18]. Considering the levels of DOC present in the river and pond water, it is apparent that the amount of ciprofloxacin biologically active against bacteria in the river water was $<25 \mu \mathrm{g} \cdot \mathrm{L}^{-1}$. Similarly, the portion of ciprofloxacin that was active against bacteria in the pond water, with a DOC concentration approximately 15 times that of the river water, was likely significantly $<1000 \mu \mathrm{g} \cdot \mathrm{L}^{-1}$. It should also be noted that when antibiotics are used in broth solutions or agar plates within the lab, there may be binding of the antibiotic to constituents of the media thereby causing a portion of it to become inactive and therefore the active antibiotic concentration may be overestimated.

The binding of ciprofloxacin to DOC and other ions and metals in the pond water is the likely reason for the higher concentration of ciprofloxacin required to inhibit DNA production in pond water bacteria. While the exact reason for the differences between the inhibition in DNA production is unknown, some reasons for the differences can include: the phase of bacterial growth in the two water systems with bacteria in log phase being more susceptible to antibiotics; higher sensitivity to ciprofloxacin by the bacteria in the river water compared to pond water; and higher resistance to antibiotics by microbes in the pond water since they may be exposed to fluxes of natural antibiotics from the surrounding farm fields as well as from within the pond. However, the differences in DNA inhibition between the two waters are unclear and further study is required. Furthermore, the higher incorporation of ${ }^{3} \mathrm{H}$ thymidine in the river water microbes compared to the microbes in the pond water is also unknown and requires further investigations.

Although we are not aware of any other work that has utilized the ${ }^{3} \mathrm{H}$ thymidine incorporation method to measure the impacts of antibiotics on microbes in environmental waters, the present work has shown that the ${ }^{3} \mathrm{H}$ thymidine incorporation method, in the presence of a DNA inhibiting antibiotic, is extremely sensitive. We have also shown that even at parts per billion concentrations microbes are extremely sensitive to antibiotics and their metabolic activities are significantly affected. The implica- 
tion of our work is that: if the antibiotics used are so inhibitory at low concentrations, there may be many natural antibiotics, produced in trace amounts and which have thus far not been identified, isolated and may not even be extractable; and the concentrations at which susceptible microbes are affected by antibiotics are extremely low, as evidenced by our assay, and therefore, the significance of antibiotics on microbes and microbial ecology is underestimated.

\section{Acknowledgements}

We thank Dr. Marley Waiser (now retired) of the National Water Research Institute of Environment Canada for the use of laboratory space and equipment.

\section{References}

[1] Mincer, T.J., Jensen, P.R., Kauffman, C.A. and Fenical, W. (2002) Widespread and Persistent Populations of a Major New Marine Actinomycete Taxon in Ocean Sediments. Applied and Environmental Microbiology, 68, 5005-5011.

http://dx.doi.org/10.1128/AEM.68.10.5005-5011.2002

[2] Nester, E.W. (2004) Microbiology: A Human Perspective. 4th Edition, McGraw-Hill, Boston.

[3] Wiegand, I., Hilpert, K. and Hancock, R.E. (2008) Agar and Broth Dilution Methods to Determine the Minimal Inhibitory Concentration (MIC) of Antimicrobial Substances. Nature Protocols, 3, 163-175. http://dx.doi.org/10.1038/nprot.2007.521

[4] Riddle, C., Lemons, C.L., Papich, M.G. and Altier, C. (2000) Evaluation of Ciprofloxacin as a Representative of Veterinary Fluoroquinolones in Susceptibility Testing. Journal of Clinical Microbiology, 38, 1636-1637.

[5] Vieno, N.M., Tuhkanen, T. and Kronberg, L. (2006) Analysis of Neutral and Basic Pharmaceuticals in Sewage Treatment Plants and in Recipient Rivers Using Solid Phase Extraction and Liquid Chromatography-Tandem Mass Spectrometry Detection. Journal of Chromatography A, 1134, 101-111. http://dx.doi.org/10.1016/j.chroma.2006.08.077

[6] Karthikeyan, K.G. and Meyer, M.T. (2006) Occurrence of Antibiotics in Wastewater Treatment Facilities in Wisconsin, USA. Science of the Total Environment, 361, 196-207. http://dx.doi.org/10.1016/j.scitotenv.2005.06.030

[7] Aldred, K.J., Kerns, R.J. and Osheroff, N. (2014) Mechanism of Quinolone Action and Resistance. Biochemistry, 53, 1565-1574. http://dx.doi.org/10.1021/bi5000564

[8] Hartmann, A., Golet, E.M., Gartiser, S., Alder, A.C., Koller, T. and Widmer, R.M. (1999) Primary DNA Damage But Not Mutagenicity Correlates with Ciprofloxacin Concentrations in German Hospital Wastewaters. Archives of Environmental Contamination and Toxicology, 36, 115-119. http://dx.doi.org/10.1007/s002449900449

[9] Li, W., Shi, Y., Gao, L., Liu, J. and Cai, Y. (2013) Occurrence, Distribution and Potential Affecting Factors of Antibiotics in Sewage Sludge of Wastewater Treatment Plants in China. Science of the Total Environment, 445-446, 306-313. http://dx.doi.org/10.1016/j.scitotenv.2012.12.050

[10] Chow, L., Waldron, L. and Gillings, M.R. (2015) Potential Impacts of Aquatic Pollutants: Sub-Clinical Antibiotic Concentrations Induce Genome Changes and Promote Antibiotic Resistance. Frontiers in Microbiology, 6, 803. http://dx.doi.org/10.3389/fmicb.2015.00803

[11] World Health Organization (2014) Antimicrobial Resistance: Global Report on Surveil- 
lance. World Health Organization.

[12] Tumber, V.P., Robarts, R.D., Arts, M.T., Evans, M.S. and Caldwell, D.E. (1993) The Influence of Environmental Factors on Seasonal Changes in Bacterial Cell Volume in Two Prairie Saline Lakes. Microbial Ecology, 26, 9-20. http://dx.doi.org/10.1007/BF00166025

[13] Verma, B., Robarts, R.D. and Headley, J.V. (2007) Impacts of Tetracycline on Planktonic Bacterial Production in Prairie Aquatic Systems. Microbial Ecology, 54, 52-55. http://dx.doi.org/10.1007/s00248-006-9170-5

[14] Robarts, R.D. and Zohary, T. (1993) Fact or Fiction-Bacterial Growth Rates and Production as Determined by (Methyl-3H)-Thymidine? Advances in Microbial Ecology, 13, 371425. http://dx.doi.org/10.1007/978-1-4615-2858-6_9

[15] Hawkey, P.M. (2003) Mechanisms of Quinolone Action and Microbial Response. Journal of Antimicrobial Chemotherapy, 51, 29-35. http://dx.doi.org/10.1093/jac/dkg207

[16] Cardoza, L.A., Knapp, C.W., Larive, C.K., Belden, J.B., Lydy, M. and Graham, D.W. (2005) Factors Affecting the Fate of Ciprofloxacin in Aquatic Field Systems. Water Air and Soil Pollution, 161, 383-398. http://dx.doi.org/10.1007/s11270-005-5550-6

[17] Aristilde, L. and Sposito, G. (2013) Complexes of the Antimicrobial Ciprofloxacin with Soil, Peat, and Aquatic Humic Substances. Environmental Toxicology and Chemistry, 32, 14671478. http://dx.doi.org/10.1002/etc.2214

[18] Verma, B., Headley, J.V. and Robarts, R.D. (2007) Behaviour and Fate of Tetracycline in River and Wetland Waters on the Canadian Northern Great Plains. Journal of Environmental Science and Health Part A: Toxic/ Hazardous Substances \& Environmental Engineering, 42, 109-117. http://dx.doi.org/10.1080/10934520601011163

\section{Submit or recommend next manuscript to SCIRP and we will provide best service for you:}

Accepting pre-submission inquiries through Email, Facebook, LinkedIn, Twitter, etc. A wide selection of journals (inclusive of 9 subjects, more than 200 journals)

Providing 24-hour high-quality service

User-friendly online submission system

Fair and swift peer-review system

Efficient typesetting and proofreading procedure

Display of the result of downloads and visits, as well as the number of cited articles Maximum dissemination of your research work

Submit your manuscript at: http://papersubmission.scirp.org/ 